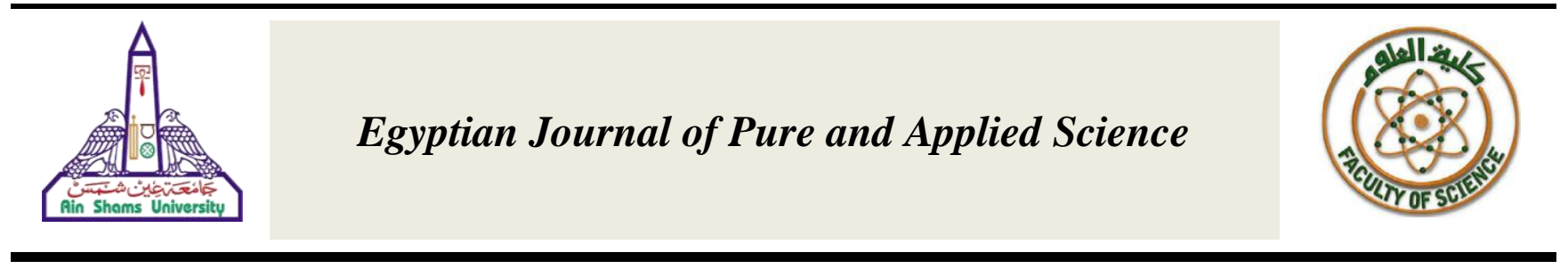

\title{
An efficient methodology for the synthesis of 4-hydroxy-8- tosyloxyquinoline-3-carboxylates
}

\author{
Walaa A. E. Omar* \\ Department of Science and Mathematics, Faculty of Petroleum and Mining Engineering, Suez University, Suez 43721, \\ Egypt
}

A R T I C L E I N F O

Article history:

Received 10 June 2014

Accepted 15 September 2014

Keywords:

8-Tosyloxyquinoline;

transesterification;

indium triiodide;

lewis acid;

$\beta$-keto ester.

\section{Introduction}

Quinoline derivatives are well known for their pharmaceutical properties ${ }^{[1-7]}$. Among the important quinoline classes are those which have an ester group at position-3. For example, alkyl 6,7-dialkoxy-4-hydroxy3-quinolinecarboxylates possessed anticoccidial activity [1] 4-Amino-3-quinolinecarboxylic acids and esters are antisecretory antiulcer compounds ${ }^{[8]}$. One of the original methods for the preparation of ethyl quionoline3 -carboxylic esters is Gould-Jacobs approach ${ }^{[3,9]}$. The method involves the reaction between a suitably substituted aniline and substituted ethylenemalonate in an addition-elimination followed by cyclization of the product.

The production of different quinolinecarboxylates other than methyl and ethyl ester is usually performed by heating the methyl or ethyl quinolinecarboxylate with the appropriate alcohol at high temperature in the presence of a protic acid or base catalyst ${ }^{[\mathbf{1 , 4 , 1 0 - 1 3}]}$. Such procedure is time consuming as it may take several days besides its limited success with branched and olefinic alcohols. Moreover, transesterification in multifunctional quinolinecarboxylates is problematic to happen selectively on the ester group. Recently, many research groups devoted their efforts to develop more efficient and versatile catalysts for the transesterification reaction to avoid the traditional protic acid and base catalyst complications. In this context, 4- $(N, N-$ dimethylamino)pyridine (4-DMAP) [13], cobalt complexes [14], zeolites ${ }^{[15]}$, amberlyst-15 ${ }^{[16]}$, palladium catalysts ${ }^{[17]}$, titanium alkoxides ${ }^{[18]}$, boric acid ${ }^{[19]}$, and

\footnotetext{
* Corresponding author.

E-mail address: walaa.abbas.omar@gmail.com
}

lewis acids ${ }^{[20,21]}$ have been successfully employed. Ranu et al. ${ }^{[21]}$ reported indium triiodide as an effective lewis acid to catalyze the transesterification of a variety of aliphatic and aromatic esters with alcohols. The advantages of this method are the non-toxicity of the reagent, very clean and the mild reaction conditions. Although the importance of quinoline-3-carboxylic acid esters, to our knowledge, transesterification catalyzed with non protic acids has not been yet investigated in this class of quinolines.

In this paper the authors developed an efficient synthetic route for the preparation of different ester derivatives of 4-hydroxy-8-tosyloxyquinolin-3-caroxylates. The starting ester, ethyl 4-hydroxy-8-tosyloxyquinoline-3carboxylate 3, was prepared via Gould-Jacobs approach after protecting the hydroxyl group at C-8 with a tosyl group. Different ester derivatives were prepared from 3 by clean and efficient transesterification reaction using indium triiodide as a catalyst.

\section{Materials and Methods}

\section{General}

Melting points were determined using METTLER TOLEDO DSC 821 thermo analyzer. NMR $\left({ }^{1} \mathrm{H}\right.$ and $\left.{ }^{13} \mathrm{C}\right)$ analysis were performed on bruker DPX $200(200 \mathrm{MHz})$ spectrometer using DMSO- $d_{6}$ solution referenced internally to $\mathrm{Me}_{4} \mathrm{Si}, J$ values are given in $\mathrm{Hz}$. TLC were performed on dry silica gel plates and developed by using chloroform/ methanol mixture as eluent. The starting material diethyl 2-[(2-hydroxyanilino) methylene]propanedioate $\mathbf{1}$ has been prepared according to the earlier reported procedures ${ }^{[22,23]}$. 
Synthesis of diethyl 2-[[2-(p-tolylsulphonyloxy) anilino]methylene]propanedioate (2)

Diethyl 2-[(2-hydroxyanilino)methylene]propanedioate 1 (7 g, $25 \mathrm{mmol}$ ) was stirred with $1 \mathrm{M} \mathrm{NaOH}$ (aq) (25 $\mathrm{mL})$ for $30 \mathrm{~min}$. Then $p$-toluenesulphonyl chloride $(4.8$ $\mathrm{g}, 25 \mathrm{mmol})$ dissolved in ethanol $(12 \mathrm{~mL})$ was added and the mixture was stirred for $30 \mathrm{~min}$. More water was added $(13 \mathrm{~mL})$ to the mixture and stirring was continued for more $10 \mathrm{~min}$. The precipitate formed was collected by filtration and washed with distilled water to give the title compound in a pure form as yellowish powder of mp 103-104 ${ }^{\circ} \mathrm{C}$, yield $10.7 \mathrm{~g}, 99 \% .{ }^{1} \mathrm{H}$ NMR (200 M Hz, DMSO- $\left.d_{6}\right) \delta 1.22(\mathrm{t}, J=7.1 \mathrm{~Hz}, 3 \mathrm{H}), 1.28(\mathrm{t}, J=7.1 \mathrm{~Hz}$, $3 \mathrm{H}), 2.32$ (s, 3H), 4.04-4.15 (q, $J=7.2 \mathrm{~Hz}, 2 \mathrm{H}), 4.18$ 4.29 (q, $J=7.2 \mathrm{~Hz}, 2 \mathrm{H}), 7.19-7.65(\mathrm{~m}, 8 \mathrm{H}), 7.98-8.05$ (d, $J=13.3 \mathrm{~Hz}, 1 \mathrm{H}), 10.64-10.71(\mathrm{~d}, J=13.3 \mathrm{~Hz}, 1 \mathrm{H})$; ${ }^{13} \mathrm{C}$ NMR (50 MHz, DMSO-d $) \delta 14.7$ (2C), 21.6, 60.1, 60.5, 95.1, 118.3, 124.2, 125.7, 128.7 (2C), 129.3, 130.5 (2C), 131.1, 132.8, 138.9, 146.9, 151.2, 164.9, 167.9. HRMS $(\mathrm{M}+\mathrm{Na})^{+}$calc for $\mathrm{C}_{21} \mathrm{H}_{23} \mathrm{NO}_{7} \mathrm{NaS}$ : 456.1093, found: 456.1086 .

Synthesis of ethyl 4-hydroxy-8-(p-tolylsulphonyloxy) quinolone-3-carboxylate (3)

Diethyl 2-[[2-(p-tolylsulphonyloxy)anilino]methylene] propanedioate $2(9.2 \mathrm{~g}, 21 \mathrm{mmol})$ and diphenylether (75 $\mathrm{mL}$ ) were stirred and heated in a dry round bottom flask at $240-250^{\circ} \mathrm{C}$ for $1 \mathrm{~h}$. The reaction mixture was then cooled to room temperature and gradually poured over $200 \mathrm{~mL}$ petroleum ether with stirring. The precipitate formed was collected by filtration, washed with petroleum ether and recrystallized from ethanol affording the title compound as colorless needles (mp 191-192 ${ }^{\circ} \mathrm{C}$, yield $\left.7.8 \mathrm{~g}, 95 \%\right) .{ }^{1} \mathrm{H}$ NMR (200 $\mathrm{MHz}$, DMSO-d $d_{6} \delta 1.21-1.28(\mathrm{t}, J=7.4 \mathrm{~Hz}, 3 \mathrm{H}), 2.34(\mathrm{~s}, 3 \mathrm{H})$, 4.14-4.24 (q, $J=6.9 \mathrm{~Hz}, 2 \mathrm{H}), 7.36-7.43$ (m, 4H), 7.74$7.78(\mathrm{~d}, J=8.3 \mathrm{~Hz}, 2 \mathrm{H}), 8.04-8.06(\mathrm{~d}, J=7.9 \mathrm{~Hz}, 1 \mathrm{H})$, 8.22-8.25 (d, $J=6.9 \mathrm{~Hz}, 1 \mathrm{H}), 12.01-12.04(\mathrm{~d}, J=7.06$ $H z, 1 \mathrm{H}) ;{ }^{13} \mathrm{C}$ NMR $\left(50 \mathrm{MHz}, \mathrm{DMSO}-d_{6}\right) \delta 14.7,21.6$, $60.3,110.9,124.8,125.0,125.2,129.2(3 \mathrm{C}), 130.6(2 \mathrm{C})$, 130.7, 132.4, 138.7, 145.2, 147.0, 164.7, 172.9. HRMS $(\mathrm{M}+\mathrm{H})^{+}$calc for $\mathrm{C}_{19} \mathrm{H}_{18} \mathrm{NO}_{6} \mathrm{~S}$ : 388.0855, found: 388.0855 .

\section{General procedures for the transesterification reaction}

Ethyl 4-hydroxy-8-( $p$-tolylsulphonyloxy)quinolone-3carboxylate $3(200 \mathrm{mg}, 0.52 \mathrm{mmol})$ was refluxed for $1 / 2$ $7 \mathrm{~h}$ in a dry alcoholic solution of indium triiodide, prepared in situ by stirring indium metal slices $(89 \mathrm{mg}$, $0.78 \mathrm{mmol}$ ) and iodine (295 $\mathrm{mg}, 1.17 \mathrm{mmol}$ ) in excess of the proper alcohol (15 mL) overnight. Molecular sieves $4 \AA$ were added to the reaction mixture to ensure dryness and absorb the formed ethanol. The reaction mixture was filtered and the excess alcohol was evaporated under vacuum. The residue formed was washed with water and purified either by recrystallization or flash chromatography.
Synthesis of butyl 4-hydroxy-8-(p-tolylsulphonyloxy) quinoline-3-carboxylate (4a)

The title compound was prepared according to the general procedures for the transesterification reaction. The alcohol used was $n$-butanol and the reaction time was $30 \mathrm{~min}$. The resulting product was purified by flash chromatography using acetone/ $n$-hexane (1:1). Compound $\mathbf{4 a}$ was obtained as colorless crystals of $\mathrm{mp}$ 89-90 ${ }^{\circ} \mathrm{C}$, yield $200 \mathrm{mg}, 94 \% .{ }^{1} \mathrm{H}$ NMR (200 M Hz, DMSO- $\left.d_{6}\right) \delta 0.83-0.90(\mathrm{t}, J=7.3 \mathrm{~Hz}, 3 \mathrm{H}), 1.28-1.41$ $(\mathrm{m}, 2 \mathrm{H}), 1.52-1.62(\mathrm{~m}, 2 \mathrm{H}), 2.32(\mathrm{~s}, 3 \mathrm{H}), 4.08-4.14(\mathrm{t}, J$ $=4.1 \mathrm{~Hz}, 2 \mathrm{H}), 7.37-7.41(\mathrm{~m}, 4 \mathrm{H})), 7.71-7.75(\mathrm{~m}, 2 \mathrm{H})$, 8.0-8.04 (d, $J=8.2 \mathrm{~Hz}, 1 \mathrm{H}), 8.27$ (s, 1H), 12.03 (br.s, $1 \mathrm{H}, \mathrm{OH}$ exchangeable); ${ }^{13} \mathrm{C}$ NMR (50 MHz, DMSO- $d_{6}$ ) $\delta$ 14.1, 19.2, 21.7, 30.7, 64.2, 110.4, 125.0, 125.1, $125.4,129.1,129.2$ (2C), 130.6 (3C), 132.3, 138.6, $145.5,147.1,164.8,173.4$. HRMS $(\mathrm{M}+\mathrm{H})^{+}$calc for $\mathrm{C}_{21} \mathrm{H}_{22} \mathrm{NO}_{6} \mathrm{~S}: 416.1168$, found: 416.1167.

Synthesis of isopropyl 4-hydroxy-8-(p-tolylsulfonyloxy) quinoline-3-carboxylate (4b)

The title compound was prepared according to the general procedure for transesterification reaction. The alcohol used was isopropyl alcohol and the reaction time was $7 \mathrm{~h}$. The resulting product was recrystallized from aqueous ethanol affording $\mathbf{4 b}$ as yellowish crystals of mp 88-9 ${ }^{\circ} \mathrm{C}$, yield $184 \mathrm{mg}, 89 \%$. ${ }^{1} \mathrm{H}$ NMR $(200 \mathrm{MHz}$, DMSO- $\left.d_{6}\right) \delta 1.24-1.27(\mathrm{~d}, J=6.1 \mathrm{~Hz}, 6 \mathrm{H}), 2.36(\mathrm{~s}, 3 \mathrm{H})$, 4.96-5.10 (m, 1H), 7.33-7.47 (m, 4H), 7.75-7.79 (d, $J=$ $8.2 \mathrm{~Hz}, 2 \mathrm{H}), 8.02-8.06(\mathrm{~d}, J=7.4 \mathrm{~Hz}, 1 \mathrm{H}), 8.20-8.24$ (d, $J=5.9 \mathrm{~Hz}, 1 \mathrm{H}), 11.96-12.00(\mathrm{~d}, J=6.5 \mathrm{~Hz}, 1 \mathrm{H}, \mathrm{NH})$; ${ }^{13} \mathrm{C}$ NMR (50 MHz, DMSO-d $d_{6} \delta 21.6,22.2$ (2C), 67.6, $111.2,124.8,125.0,125.2,129.2$ (3C), 130.6, 130.7 (2C), 132.4, 138.6, 145.1, 147.1, 164.1, 173.0. HRMS $(\mathrm{M}+\mathrm{H})^{+}$calc for $\mathrm{C}_{20} \mathrm{H}_{20} \mathrm{NO}_{6} \mathrm{~S}$ : 402.1011, found: 402.1020 .

Synthesis of sec-butyl 4-hydroxy-8-(p-tolylsulfonyloxy) quinoline-3-carboxylate (4c)

The title compound was prepared according to the general procedure for transesterification reaction. The alcohol used was secbutyl alcohol and the reaction time was $7 \mathrm{~h}$. The resulting product was purified by flash chromatography using acetone/ $n$-hexane $(1: 1)$ as eluent affording $\mathbf{4 c}$ as yellowish crystals of mp $92-93^{\circ} \mathrm{C}$, yield $193 \mathrm{mg}, 90 \% .{ }^{1} \mathrm{H}$ NMR (200 MHz, DMSO- $\left.d_{6}\right) \delta 0.86(\mathrm{t}$, $J=7.6 \mathrm{~Hz}, 3 \mathrm{H}), 1.1(\mathrm{~d}, J=6.72 \mathrm{~Hz}, 3 \mathrm{H}), 1.57$ (quintet, $J$ $=7.2 \mathrm{~Hz}, J=7.2 \mathrm{~Hz}, 2 \mathrm{H}), 2.32(\mathrm{~s}, 3 \mathrm{H}), 4.84$ (sextet, $J=$ $6.2 \mathrm{~Hz}, 1 \mathrm{H}), 7.32(\mathrm{~m}, 4 \mathrm{H}), 7.72(\mathrm{~d}, J=7.4 \mathrm{~Hz}, 2 \mathrm{H}), 8.01$ (d, $J=7.39 \mathrm{~Hz}, 1 \mathrm{H}), 8.25$ (s, 1H), 12.0 (br.s, $1 \mathrm{H}, \mathrm{OH}$ exchangeable); ${ }^{13} \mathrm{C}$ NMR (50 MHz, DMSO- $\left.d_{6}\right) \delta 10.0$, $19.9,21.7,28.7,72.1,110.8,119.0,125.0$ (2C), 125.3, 129.1 (2C), 130.6 (3C), 132.4, 138.6, 145.2, 147.0, 164.3, 173.3. HRMS $(\mathrm{M}+\mathrm{H})^{+}$calc for $\mathrm{C}_{21} \mathrm{H}_{22} \mathrm{NO}_{6} \mathrm{~S}$ : 416.1168, found: 416.1175.

Synthesis of allyl 4-hydroxy-8-(p-tolylsulfonyloxy) quinolone-3-carboxylate (4d)

The title compound was prepared according to the general procedures for the transesterification reaction. 
The alcohol used was allyl alcohol and the reaction time was $30 \mathrm{~min}$. The resulting product was recrystallized from ethanol giving $\mathbf{4 d}$ as white needles of $\mathrm{mp} 178-179^{\circ} \mathrm{C}$, yield $186 \mathrm{mg}, 90 \%$. ${ }^{1} \mathrm{H}$ NMR (200 $\left.\mathrm{MHz}, \mathrm{DMSO}-d_{6}\right) \delta 2.35(\mathrm{~s}, 3 \mathrm{H}), 4.68(\mathrm{~d}, J=5.2 \mathrm{~Hz}$, 2H), 5.21-5.48 (m, 2H), 5.89-6.05 (m, 1H), 7.37-7.48 (m, 4H), $7.75(\mathrm{~d}, J=7.9 \mathrm{~Hz}, 2 \mathrm{H}), 8.03(\mathrm{~d}, J=7.9 \mathrm{~Hz}$, $1 \mathrm{H}), 8.26$ (s, 1H), 12.04 (br.s, 1H, OH exchangeable); ${ }^{13} \mathrm{C}$ NMR (50 MHz, DMSO- $\left.d_{6}\right) \delta 21.6,64.7,110.6$, $117.8,124.8,125.0,125.3,129.2$ (3C), 130.6 (3C), 132.4, 133.3, 138.7, 145.5, 147.1, 164.4, 172.8. HRMS $(\mathrm{M}+\mathrm{H})^{+}$calc for $\mathrm{C}_{20} \mathrm{H}_{18} \mathrm{NO}_{6} \mathrm{~S}:$ 400.0855, found: 400.0855 .

Synthesis of benzyl 4-hydroxy-8-(p-tolylsulfonyloxy) quinoline-3-carboxylate $(\mathbf{4 e})$

The title compound was prepared according to the general procedure for the transesterification reaction. The $\mathrm{In} / \mathrm{I}_{2}$ mixture was stirred in benzyl alcohol overnight at $90-100{ }^{\circ} \mathrm{C}$ then compound 3 and $\mathrm{MS} 4 \AA$ were added and the mixture was stirred at $120{ }^{\circ} \mathrm{C}$ for 1 $\mathrm{h}$. The reaction mixture was then allowed to cool to room temperature and filtered. The filtrate was charged in a silica gel column and eluated by $\mathrm{CHCl}_{3}$ followed by a second eluation with $\mathrm{CHCl}_{3} / \mathrm{MeOH}(10: 1)$ to afford the title compound as white powder of mp 195$196{ }^{\circ} \mathrm{C}$, yield $181 \mathrm{mg}, 78 \%$. ${ }^{1} \mathrm{H}$ NMR (200 $\mathrm{MHz}$, DMSO- $\left.d_{6}\right) \delta 2.33(\mathrm{~s}, 3 \mathrm{H}), 5.25(\mathrm{~s}, 2 \mathrm{H}), 7.29-7.49(\mathrm{~m}$, 9H), $7.74(\mathrm{~d}, J=8.1 \mathrm{~Hz}, 2 \mathrm{H}), 8.04(\mathrm{~d}, J=8.6 \mathrm{~Hz}, 1 \mathrm{H})$, 8.28 (s, 1H), 12.05 (br.s, $1 \mathrm{H}, \mathrm{OH}$ exchangeable); ${ }^{13} \mathrm{C}$ NMR (50 MHz, DMSO-d 6 ) $\delta$ 21.6, 65.8, 110.5, 124.9, 125.0, 125.3, 126.8, 128 (2C), 128.9 (2C), 129.2 (3C), 130.6 (3C), 132.4, 137.0, 138.7, 145.6, 147.0, 164.7, 172.9. HRMS $(\mathrm{M}+\mathrm{H})^{+}$calc for $\mathrm{C}_{24} \mathrm{H}_{20} \mathrm{NO}_{6} \mathrm{~S}: 450.1011$, found: 450.1018

\section{Results and discussion}

The starting material, diethyl 2-[(2hydroxyanilino)methylene]propanedioate $\mathbf{1}$, was prepared by refluxing 2-aminophenol and diethyl ethoxymethylene malonate in ethanol for $1 \mathrm{~h}$. The reaction could be performed in large scale (12 $\mathrm{g}$ of 2aminophenol) affording 1 in high yield (95\%). Before cyclization reaction of $\mathbf{1}$, the phenolic hydroxyl group was protected with a tosyl group. The protection is a prerequisite to avoid the participation of the phenolic hydroxyl in any consequent reactions ${ }^{[24]}$. The tosyl group has been chosen as a protecting group because it can tolerate the acidic medium employed in the transesterification reaction ${ }^{[25-27]}$. In addition, it has been reported that the tosyl group can be removed selectively after completion of the desired reactions by a suitable alkoxide. The protection of the hydroxyl group in $\mathbf{1}$ took place smoothly using $\mathrm{TsCl}$ and the reaction was successfully scaled up at room temperature affording diethyl 2-[[2-(p-tolylsulphonyloxy)anilino]methylene] propanedioate 2 in excellent yield (99\%). The cyclization of 2 was carried out at $250^{\circ} \mathrm{C}$ by applying Gould Jacobs type cyclization reaction affording ethyl 4-hydroxy-8-(ptolylsulfonyloxy)quinolone-3-carboxylate $\mathbf{3}$ in high yield $(95 \%)$. The overall synthetic route for compound $\mathbf{3}$ is illustrated in Scheme 1.

Theoretically, compound $\mathbf{3}$ can exist in two forms $\mathbf{3 a}$ and 3b, Scheme 2. ${ }^{1} \mathrm{H}$ NMR analysis for compound 3 showed a clear coupling between $\mathrm{N}-\mathrm{H}$ and $\mathrm{C}-2$ protons which indicates the existence of $\mathbf{3}$ as 4-quinolone derivative (3b) only, Fig 1. Similar coupling between the N-H and C-2 protons in 4-hydroxy-8tosyloxyquinoline was observed by Heiskanen et al ${ }^{[28]}$.

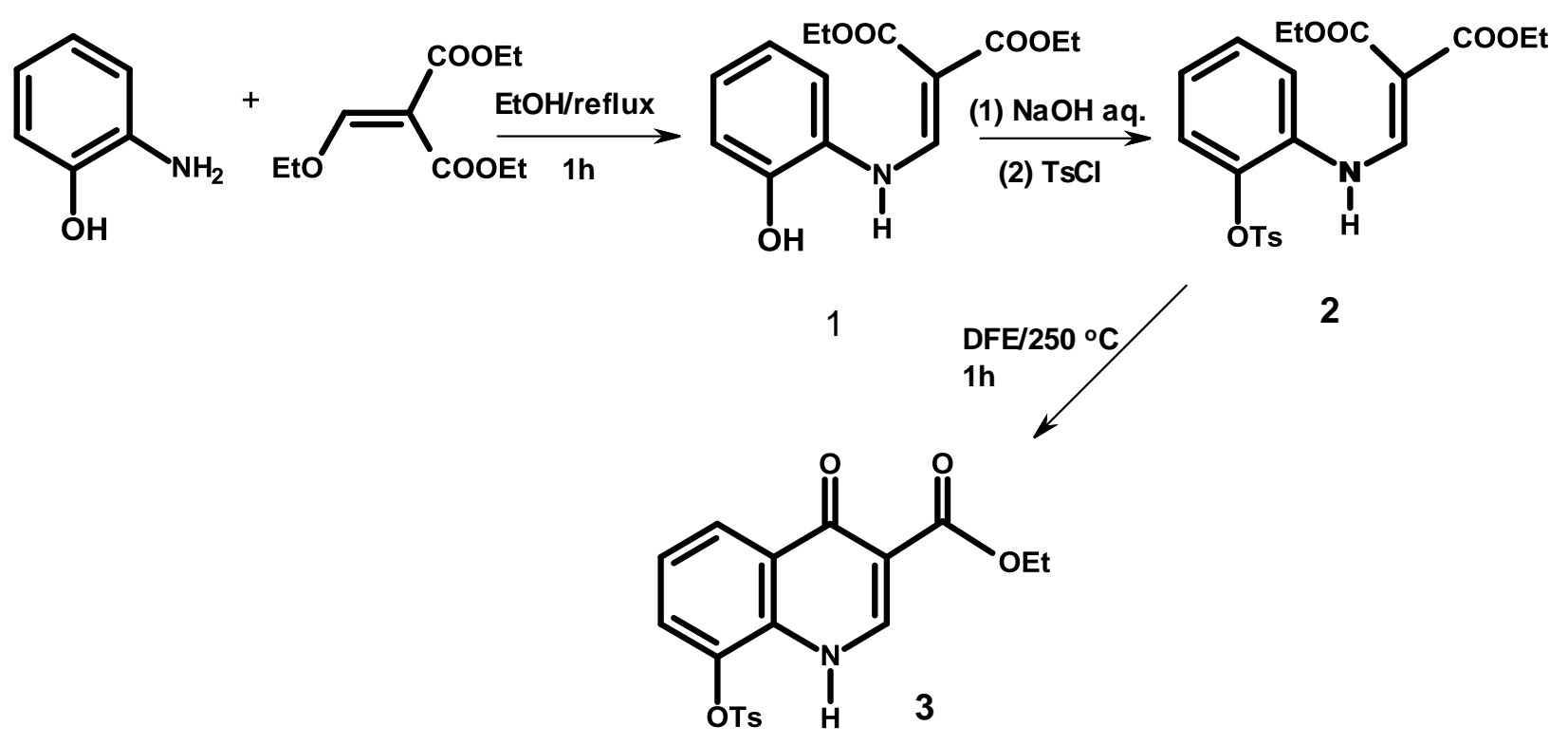

Scheme 1: The synthetic route for ester 3 


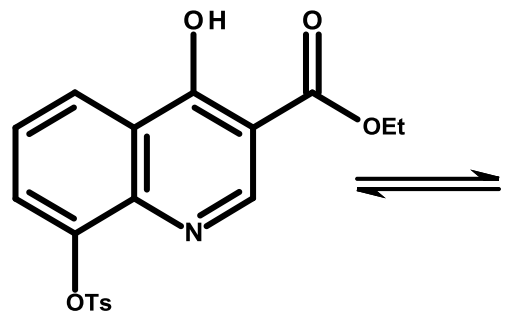

3a<smiles>CCOC(=O)c1c[nH]c2c([O-])cccc2c1=O</smiles>

$3 b$

Scheme 2: Compound $\mathbf{3}$ can exist in two forms, $\mathbf{3 a}$ and $\mathbf{3 b}$.

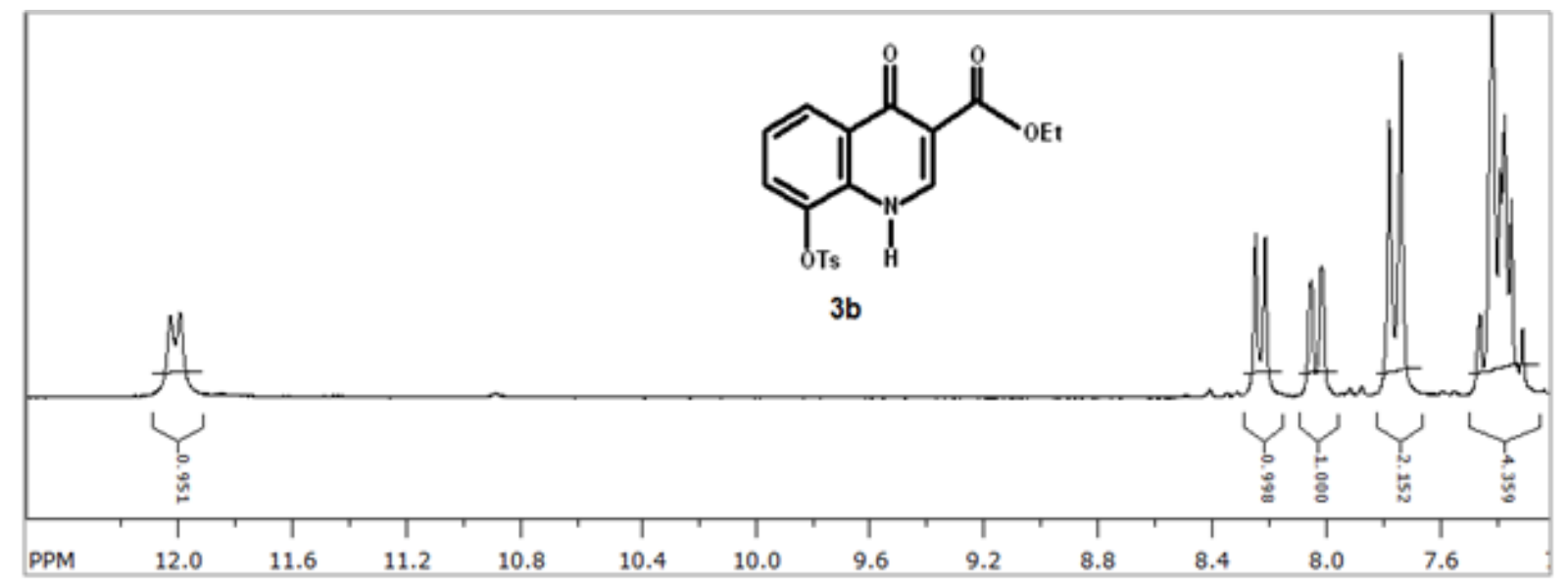

Fig. 1: The ${ }^{1} \mathrm{H}$ NMR spectrum for compound 3 shows coupling between $\mathrm{N}-\mathrm{H}$ and $\mathrm{C}-2$ proton.

Preliminary tests for the transesterification reaction by heating 3 with $n$-butanol in the presence of a protic acid catalyst resulted in hydrolysis of the ester group forming the corresponding acid after long reaction time $(24 \mathrm{~h})$. Transesterification of $\mathbf{3}$ with $n$-butanol in the presence of catalytic amount of boric acid or $4-(N, N-$ dimethylamino)pyridine (DMAP) failed and the starting material was recovered even after prolonged reaction time $(24 \mathrm{~h})$.

A successful transesterification reaction for the ethyl ester in compound $\mathbf{3}$ with $n$-butanol could be achieved by using Indium triiodide as the catalyst. The transesterification reaction is an equilibrium process, therefore molecular sieves $4 \AA$ were used to absorb the liberated ethanol from the reaction media and shifting the equilibrium towards the formation of the product $4 \mathbf{a}$. Although the reaction could proceed using 0.75 equivalent of $\mathrm{InI}_{3}$, the use of 1.5 equivalent shortened the reaction time dramatically. After optimization of the reaction conditions, the desired transesterification reaction with different alcohols such as iso-propyl, secbutyl, allyl and benzyl alcohol went smoothly affording the desired products $\mathbf{4 b - e}$ in high yields (Scheme $\mathbf{3}$ ).

Ranu et al. ${ }^{[21]}$ reported that the use of 1.5 equivalent of $\mathrm{InI}_{3}$ reduces the transesterification reaction time to be 5$6 \mathrm{~h}$ in case of aliphatic esters and 25-30 $\mathrm{h}$ in case of aromatic esters. In this work, although our starting ester was aromatic (compound 3 ), the use of 1.5 equivalent of $\mathrm{InI}_{3}$ shortened the reaction time to be only $1 / 2-7 \mathrm{~h}$ depending on the structure of the alcohol used in the transesterification (Table 1). Aliphatic primary alcohol such as $n$-butanol has replaced the ethoxy group of $\mathbf{3}$ in 30 minutes (entry 1, Table 1) while transestrification by iso-propanol and sec-butanol took $7 \mathrm{~h}$ (entry 2, 3, Table 1).

Transesterification with allyl alcohol is known to be difficult as it may undergo the Carroll rearrangement ${ }^{[9,29}$ 31]. However the reaction of $\mathbf{3}$ with allyl alcohol (entry 4, Table 1) proceeded smoothly giving the corresponding ester product $\mathbf{4 d}$ within $30 \mathrm{~min}$.

Goswami et al. ${ }^{[32]}$ reported that, long chain aliphatic alcohols and benzylic alcohols reacted easily with methyl acetoacetate in the presence of a catalytic amount of $\mathrm{Al}\left(\mathrm{H}_{2} \mathrm{PO}_{4}\right)_{3}$, while the tertiary alcohols failed to undergo the transesterification. On the other hand, a successful catalytic transesterification between $\beta$-ketoesters and tertalcolohs has been carried out using ceria-yttria based lewis acid and $\mathrm{ZnO}$ as catalysts ${ }^{[33,34]}$. During this work, although $\mathrm{InI}_{3}$ transesterification of $\mathbf{3}$ with primary, secondary, allyl and benzyl alcohols was feasible, the reaction with tert-alcohols such as tert-butyl and tertamyl alcohol was problematic as no transesterification product was formed under the applied conditions even after prolonged reaction time (24 h) (entry 5, 6, Table 1). 
<smiles>CCOC(=O)c1c[nH]c2c(OC(F)(F)F)cccc2c1=O</smiles>

3

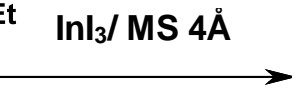
ROH

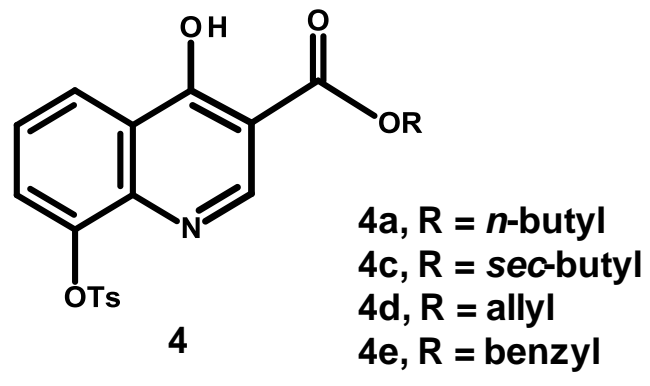

Scheme 3: The synthetic route for compounds 4a-e. ${ }^{1}$ HNMR spectra revealed that compounds $4 \mathbf{a}$ and $4 \mathbf{c}-\mathbf{e}$ exist mainly as 4-hydroxyquinoline derivatives, while compound $\mathbf{4 b}$ (where $\mathrm{R}=$ isopropyl) exists mainly as 4-quinolone derivative.

Table 1: Transesterification of $\mathbf{3}$ with different alcohols.

\begin{tabular}{cccc}
\hline Entry & Alcohol & Reaction time (h) & Product $\left.^{\mathbf{a}} \mathbf{\%}\right)^{\mathbf{b}}$ \\
\hline $\mathbf{1}$ & $\mathrm{CH}_{3}\left(\mathrm{CH}_{2}\right)_{3} \mathrm{OH}$ & $1 / 2$ & $\mathbf{4 a}(94)$ \\
$\mathbf{2}$ & $\left(\mathrm{CH}_{3}\right)_{2} \mathrm{CHOH}$ & 7 & $\mathbf{4 b}(89)$ \\
$\mathbf{3}$ & $\mathrm{CH}_{3} \mathrm{CH}_{2} \mathrm{CH}(\mathrm{OH}) \mathrm{CH}_{3}$ & 7 & $\mathbf{4 c}(90)$ \\
$\mathbf{4}$ & $\mathrm{CH}_{2}=\mathrm{CHCH}_{2} \mathrm{OH}$ & $1 / 2$ & $\mathbf{4 d}(90)$ \\
$\mathbf{5}$ & $\left(\mathrm{CH}_{3}\right)_{3} \mathrm{COH}$ & 24 & No reaction \\
$\mathbf{6}$ & $\mathrm{CH}_{3} \mathrm{CH}_{2} \mathrm{C}(\mathrm{OH})\left(\mathrm{CH}_{3}\right)_{2}$ & 24 & No reaction \\
$\mathbf{7}$ & $\mathrm{PhCH}_{2} \mathrm{OH}$ & 1 & $\mathbf{4 e}(78)$ \\
\hline
\end{tabular}

${ }^{\mathrm{a}}$ reaction time in hours, ${ }^{\mathrm{b}}$ isolated yield between brackets.

In general, this noticeable short transesterification reaction time might be attributed to two factors. First is the use of molecular sieves ${ }^{13}$ during the reactions, which shift the equilibrium towards the formation of the product by absorbing the liberated ethanol. Second is the reactivity of $\mathbf{3}$, which is attributed to the $\beta$-keto ester structure of 3. Many research groups have reported that $\beta$-keto esters are specifically active towards transesterification reaction more than other types of ester ${ }^{[32-36]}$. Balaji et al. ${ }^{[36]}$ referred that to the enol form that enables it to undergo facile and efficient transesterification reactions with different types of alcohol. Similar reactivity was also observed during the non-catalyzed aminolysis of the quinoline derivative, methyl 5-chloro-1,2-dihydro-4-hydroxy-1methyl-2-oxoquinoline-3-carboxylate 5, Fig. $2^{[37]}$. A suggested mechanism for the $\mathrm{InI}_{3}$ catalyzed transesterification of $\mathbf{3}$ with different alcohols involves the formation of a cyclic intermediate in which the two carbonyl oxygen atoms interacted with $\mathrm{InI}_{3}$ (lewis acid). Then the formed cyclic intermediate probably reacts with the alcohol affording products 4a-e with the elimination of the ethanol and the lewis acid (Scheme 4). The proposed mechanism of the $\mathrm{InI}_{3}$ catalyzed trans- esterification of $\mathbf{3}$ is in a good agreement with the reported efforts of Pasini et al. ${ }^{[38,39]}$ and Krishnaiah et al. [40]

During the transesterification, the alcohol involved in the reaction was used in excess. The purification of the ester products 4a-e was performed either by recrystalization or flash chromatography. The highly boiling point benzyl alcohol was also used in excess during the transesterification reaction. Therefore purification of the product 4e took place through two subsequent eluations in the same column. In the first eluation, benzyl alcohol was removed using $\mathrm{CHCl}_{3}$ leaving the product $4 \mathbf{e}$ behind in the column. Subsequent eluation with $\mathrm{CHCl}_{3} / \mathrm{MeOH}$ $(10: 1)$ released the product as a pure white powder in $78 \%$ yield.

${ }^{1}$ HNMR spectra reveal that compounds $\mathbf{4 a}$ and $\mathbf{4 c - e}$ exist as 4-hydroxyquinoline derivatives rather than 4quinolone derivatives. This finding can be attributed to the formation of hydrogen bond between the hydroxyl hydrogen and carbonyl oxygen of the ester group of compounds $\mathbf{4 a}$ and $\mathbf{4 c - e}$, which favors their existence as 4-hydroxyquinoline derivatives. On the other hand ${ }^{1}$ HNMR spectrum for the isopropyl ester $4 \mathbf{b}$ showed coupling between $\mathrm{NH}$ and $\mathrm{C}-2$ protons, which suggests the existence of $\mathbf{4 b}$ as 4 -quinolone derivative. 


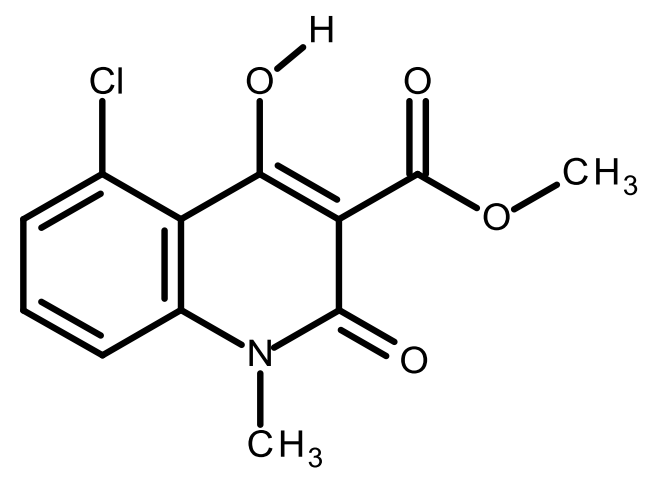

5

Fig. 2: Methyl(5-Chloro-1,2-dihydro-4-hydroxy-1-methy-2-oxo)quinoline-3-carboxylate 5.<smiles>CCOC(=O)c1c[nH]c2c(S)cccc2c1=O</smiles>

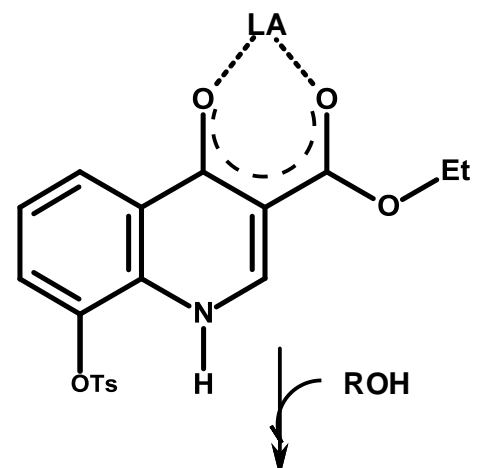<smiles>[R]OC(=O)c1c[nH]c2c([18OH])cccc2c1=O</smiles>

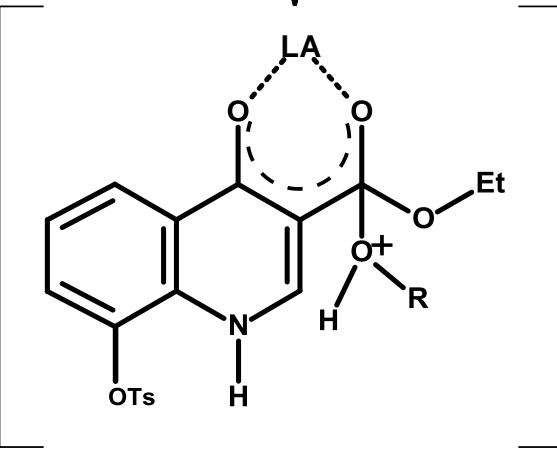<smiles>[R]OC(=O)c1cnc2c(S)cccc2c1O</smiles>

$\mathrm{LA}=\operatorname{lnI}_{3}$

Scheme 4: The mechanism of the transesterification of $\mathbf{3}$ with different alcohols to form $\mathbf{4}$ (proposed). 


\section{Conclusion}

Different 4-hydroxy-8-tosyloxyquinoline-3-carboxylates have been prepared by transesterification reaction using $\mathrm{InI}_{3}$ as a catalyst. The tosyloxy group showed high stability during the transesterification with different alcohols. The reaction was efficient and relatively fast affording the transformed products in high yields. The efficiency of the transesterification reaction of $\mathbf{3}$ is attributed to the structure of the starting material, which is likely to behave as a $\beta$-keto ester derivative in addition to the use of molecular sieves during the reaction. Transesterification by allyl alcohol was successful under the applied conditions. In general during the transesterification, the branching of the alcohol decreases its reactivity and subsequently elongate the reaction time.

\section{Acknowledgement}

The author thanks professor Osmo Hormi, University of Oulu, for the generous discussion and for affording chemicals and facilities.

\section{References}

1) Spencer, C.F., Engle, A., Yu, C.-N., Finch, R.C., Watson, E.J., Ebetino, F.F. and Johnson, C. A. (1966). Anticoccidial activity in a series of alkyl 6,7dialkoxy-4-hydroxy-3-quinolinecarboxylates. J. Med. Chem., 9: 934-936.

2) Chen, Y.L., Zacharias, J., Vince, R., Geraghty, R.J. and Wang, Z. (2012). C-6 aryl substituted 4quinolone-3-carboxylic acids as inhibitors of hepatitis C virus. Bioorg. Med. Chem., 20: 47904800.

3) Mitscher, L.A. (2005). Bacterial topoisomerase inhibitors: Quinolone and pyridine antibacterial agents. Chem. Rev., 105: 559-592.

4) Rowley, M., Leeson, P.D., Stevenson, G.I., Moseley, A.M., Stansfield, I., Sanderson, I., Robinson, L. Baker, R., Kemp, J.A., Marshall, G.R., Foster, A.C., Grimwood, S., Tricklebank, M.D. and Saywell, K.L. (1993). 3-Acyl-4hydroxyquinolin-2(1H)-ones. Systemically active anticonvulsants acting by antagonism at the glycine site of the $\mathrm{N}$ - methyl-D-aspartate receptor complex. J. med. Chem., 36: 3386-3396.

5) De Clercq, E. (2003). New inhibitors of human cytomegalovirus (HCMV) on the horizon. J. Antomicrob. Chemother., 51: 1079-1083.

6) Pattan, S.R., Dighe, N.S., Hariprasad C.K., Pattan J.S., Daithankar A.V., Gaware V.M. and Hole, M.B. (2009). Synthesis and evaluation of some new 6-fluoro-quinolin-4(1H)-one derivatives for their anti-microbial activities. J. Pharm. Sci. \& Res., 1: 55-60.

7) Oien, N.L., Brideau, R.J., Hopkins, T.A., Wieber, J.L., Knechtel, M.L., Shelly, J.A., Anstadt, R.A., Wells, P.A., Poorman, R.A., Huang, A., Vaillancourt, V.A., Clayton, T.L., Tucker, J.A. and Wathen, M.W. (2002). Broad-spectrum antiherpes activities of 4-hydroxyquinoline carboxamides, a novel class of herpes virus polymerase inhibitor. Antimicrob. Agents Chemother., 46: 724-730.

8) Munson, Jr. H.R. and Alphin, R.S. (1982), US patent 4343804 .

9) Gould, Jr. R.G. and Jacobs, W.A. (1939). The synthesis of certain substituted quinolones and 5,6benzoquinolines. J. Am. Chem. Soc., 61: 2890-2895.

10) Rehberg, C.E. and Fisher, C.H. (1944). Preparation and properties of the n-alkyl acrylates. J. Am. Chem. Soc., 66: 1203-1207.

11) Rehberg, C.E., Faucette, W.A. and Fisher, C.H. (1944). Preparation and properties of secondary and branced-chain alkyl acrylates. J. Am. Chem. Soc., 66: 1723-1724.

12) Taft, Jr R.W., Newman, M.S. and Verhoek, F.H. (1950). The kinetics of the base catalyzed methanolysis of ortho, meta and para substituted benzoates. J. Am. Chem. Soc., 72: 4511-4519.

13) Gilbert, J.C. and Kelly, T.A. (1988). Transesterification of 3-oxo esters with allylic alcohols. J. Org. Chem., 53: 449-450.

14) Hayashi, Y., Santoro, S., Azuma, Y., Himo, F., Ohshima, T. and Mashima, K.J. (2013). Enzymelike catalysis via ternary complex mechanism: alkoxy-bridged dinuclear cobalt complex mediates chemoselective $O$-esterification over $N$-amidation. J. Am. Chem. Soc., 135: 6192-6199.

15) Chavan, S.P., Pasupathy, K., Shengule, S., Shinde, V. and Anand, R. (2005). Catalytic transesterification of $\beta$-ketoesters with zeolite H-FER under solvent free conditions. ARKIVOC xiii: 162168.

16) Pal, R., Sarkar, T. and Khasnobis, S. (2012). Amberlyst-15 in organic synthesis. ARKIVOC i: 570-609.

17) Bao, Y.S., Chen, C.Y. and Huang, Z.Z. (2012). Transesterification for synthesis of carboxylates using aldehydes as acyl donors via $\mathrm{C}-\mathrm{H}$ and $\mathrm{C}-\mathrm{O}$ bond activations. J. Org. Chem., 77: 8344-8349.

18) Shapiro, G. and Marzi, M. (1997). Facile and selective O-alkyl transesterification of primary carbamates with titanium (IV) alkoxides. J. Org. Chem., 62: 7096-7097.

19) Kondaiah, G.C.M., Reddy, L.A., Babu, K.S., Gurav, V.M., Huge, K.G., Bandichhor, R., Reddy P.P., Bhattacharya, A. and Anand, R.V. (2008). Boric acid: an efficient and environmentally benign catalyst for transesterification of ethyl acetoacetate. Tetrahedron Lett., 49: 106-109.

20) Otera, J., Dan-Oh, N. and Nozaki, H. (1991). Novel template effects of distannoxane catalyst in highly efficient transesterificationm and esterification. J. Org. Chem., 56: 5307-5311.

21) Ranu, B.C., Dutta, P. and Sarkar, A. (1998). A simple and efficient procedure for transesterification catalyzed by indium triiodide. J. Org. Chem., 63: 6027-6028.

22) Sardesal, K.S. and Sunthankar, S.V. (1975). Condensation of aromatic amines with diethyl ethoxymethylenemalonate. Curr. Sci., 26: 250-252. 
23) Ilangovan, A. and Kumar, R.G. (2010). 2,2bis(ethoxycarbonyl)vinyl (BECV) as a versatile amine protecting group for selective functionalgroup transformation. Chem. Eur. J., 16: 29382943.

24) Urgaonkar, S. and Shaw, J.T. (2007). Synthesis of Kaempferitrin. J. Org. Chem., 72: 4582-4585.

25) Omar, W.A.E., Heiskanen, J.P. and Hormi, O.E.O. (2008). Synthesis of 8-hydroxyquinolines with amino and thioalkyl functionalities at position 4. J. Heterocyclic Chem., 45: 593-595.

26) Omar, W.A.E. and Hormi, O.E.O. (2009). Synthesis of 4-(2-arylvinyl)-8-hydroxyquinolines via anhydrous Heck coupling reaction and the PL properties of their Al complexes. Tetrahedron 65: $4422-4428$.

27) Heiskanen, J.P. and Hormi, O.E.O. (2009). 4Aryl-8-hydroxyquinolines from 4-chloro-8tosyloxyquinoline using a suzukui-miyaura crosscoupling approach. Tetrahedron 65: 518-524.

28) Heiskanen, J.P., Omar, W.A.E., Ylikunnari, M.K., Haavisto, K.M., Juan, M.J. and Hormi, O.E.O. (2007). Synthesis of 4-alkoxy-8hydroxyquinolines. J. Org. Chem., 72: 920-922.

29) Carroll, M. F. (1940). Addition of $\alpha, \beta$-unsaturated alcohols to the active methylene group. J. Am. Chem. Soc., 62: 704-706.

30) Kimel, W. and Cope, A.C. (1943). The rearrangement of allyl-type esters of $\beta$-keto acids. J. Am. Chem. Soc., 65: 1992-1998.

31) Otera, J. (1993). Transesterification. Chem. Rev., 93: 1449-1470.

32) Goswami, P. and Bharadwaj, S.K. (2008). $\mathrm{Al}\left(\mathrm{H}_{2} \mathrm{PO}_{4}\right)_{3}$ : An efficient and effective solid acid catalyst for transesterification of $\beta$-keto esters under solvent free condition. Catal. lett., 124: 100-104.

33) Pericas, A., Shafir, A. and Vallribera, A. (2008). Zinc(II) oxide: An efficient catalyst for selective transesterification of $\beta$-ketoesters. Tetrahedron 64: 9258-9263.

34) Pandey, R.K. and Kumar, P. (2007). A facile procedure for transesterification of $\beta$-keto esters promoted by ceria-yttria based lewis acid catalyst. Catal. Commun., 8: 1122-1125.

35) Yang, J., Ji, C., Zhao, Y., Li, Y., Jiang, S., Zhang, Z. JI, Y. and Liu, W. (2010). $\mathrm{BF}_{3} \cdot \mathrm{OEt}_{2}$ : An efficient catalyst for transesterification of $\beta$-ketoesters. Synth. Commun., 40: 957-963.

36) Balaji, B.S. and Chanda, B.M. (1998). Simple and high yielding syntheses of $\beta$-keto esters catalyzed by zeolites. Tetrahedron 54: 13237-13252.

37) Jansson, K., Fristedt, T., Olsson, A., Svensson, B. and Jönsson, S. (2007). Synthesis and reactivity of Laquinimod, a Quinoline-3-carboxamide: Intramolecular transfer of the enol proton to a nitrogen atom as plausible mechanism for ketene formation. J. Org. Chem., 71: 1658-1667.

38) Pasini, D., Righetti, P. and Rossi, P.P. (2002). Malonate crown ethers as building blocks for novel D- $\pi$-A chromophores. Org. Lett., 4: 23-26.

39) Garlaschelli, L., Messina, I., Pasini, D. and Righetti, P.P. (2002). Fullerene ylidene malonate supramolecular triads. Eur. J. Org. Chem., 33853392.

40) Krishnaiah, G., Sandeep, B., Kondhare, D., Rajanna, K.C., Narendar, R.J., Rajeshwar R.Y. and Zhubaidha, P.K. (2013). Manganese(II) salts as efficient catalysts for chemo selective transesterification of $i$-keto esters under non-conventional conditions. Tetrahedron Lett., 54: 703-706. 